\title{
Toward Sustainable Growth in Egypt, UK, and USA Economies
}

\author{
Dr. Attalla A. Abadeer \\ Professor of Economics -Faculty of commerce-Helwan University \\ Dr. Gaber M. Abdel Gawad \\ Professor of Economics - Faculty of Commerce-Helwan University
}

\begin{abstract}
In this paper we determine the main sources and forecast of sustainable economic growth in USA, and UK as large open advanced modern mixed economies, and in Egypt as emerging modern mixed economy. By analysis (SDGs) and Cobb-Douglas Production Function (C-DPF) with its developed by Solow growth model.The expected growth rate of GDP at the end of 2021 in USA, UK, and Egypt are more than 10\%, 7.25\%, and 6\% in three countries respectively. The main sources of sustainable growth are capital accumulation through investments, technological changes, good business environment, growth in the potential labor force, and/or (natural resources, human and physical capital, and technological factors), and institutional factors (such as finance and banking system, education system, healthcare, infrastructure, and political stability). These sources should be concentrated on its by policy makers in all three countries to achieve sustainable growth forever.
\end{abstract}

Keywords: Sustainable Growth - SDGs - C-DPF and Solow model.

DOI: $10.7176 / \mathrm{JESD} / 13-2-09$

Publication date: January $31^{\text {st }} 2022$

\section{1- Introduction:}

Egypt now in 2021 is one of the highest growth rate among developing countries through last five years ago, it started economic development after July 1952 revolution by depending on commend economy system until 1973 , after these years, Egypt transformed to modern mixed economic system (in which market take part government in leading economic system), that was leaded to improve economic performance sharply, because the growth of GDP in 1975-1986 averaged over 9\% a year in real terms, even in the face of an annual population growth rate of $2.8 \%$ between 1976 and 1986, and real per capita incomes increased at an average of $6 \%$ a year ${ }^{1}$.

From 1987 to 2014, Egypt started with a debt crisis of 1987, and found itself in a debt trap. The Egyptian authorities concluded a standby agreement with IMF in May 1991, this agreement, the economic reform and structural adjustment program (ERSAP). Soon after the stabilization was completed, the Egyptian economy was hit by a combination of serious events. The first of these was the onset of a financial crisis in East Asia in 1997, the second serious event was an attack on tourists on November 18, 1997 in the town of Luxor ${ }^{2}$.

Until 2010, Egyptian economy suffered from many problems, which reflected in weakness in several indicators and variables of macroeconomics, such as, low employment rate, high inflation rate, increasing budget deficit, external imbalances, with increase poverty and great share of informal sector in GDP. These problems continue and increase until June 30, 2013 revolution, which corrects the negative effects of the previous frailer.

From 2014 until 2021, the most of macroeconomics indicators have been improving, with inject big investments in all fields, which started from August 15,2014, when Egyptian authorities announced that starting work on digging new Swiz Canal, which completed on August 06, 2015, for less than one year, and pumping more investments in roads, bridges, constructions and building sectors. That leaded to improve in all indicators, especially after exchange rate liberalization on November 03,2016, where Egyptian reserves of foreign currencies jump to more than $\$ 44$ billion at the end of 2017, and unemployment rate decrease with decrease of budget deficit and increase the growth rate of GDP until reach to 5.6\% on August 2019.

As the rest of the world Egyptian economy was affected by COVID-19, despite the adverse impact of Coronavirus pandemic, Egypt is one of the few African countries expected to record a positive growth in 2020 at $3.6 \%{ }^{3}$.

UK's economy is highly developed social market and market oriented economy. It is the fifth-largest national economy in the world measured by nominal GDP, ninth-largest by Purchasing Power Parity (PPP), and twenty first-largest by GDP per capita, constituting 3.3\% of the world GDP 4 .

The economy of the United Kingdom is one of the most effective economy on the world. Britain's economic growth will accelerate next year at the fastest rate since official records began as the economy rebound by $7.3 \%$,

\footnotetext{
${ }^{1}$ Ikram, Khalid (2006), “The Egyptian Economy 1952-2000: Performance, Policies, and Issues", Routledge Studies in Middle Eastern Economies, Routledge: Great Britain and USA, P 24.

${ }^{2}$ Ibid, PP 57-84.

${ }^{3}$ Afdb.org, accessed on May 12, 2021.

${ }^{4}$ WIKIPEDIA (2021), "Economy of the UK", en.m.wikipedia.org, accessed on May 04, 2021.
} 
according to the government's independent economic forecaster. Because with covid-19 restrictions set to remain until the summer, delaying the start of the recovery, the office for budget responsibility said the economy would surge ahead in 2022 at the fastest pace since $1948^{1}$.

The US economy grew sharply by $6.4 \%$ on annual basis in the first quarter of 2021 , when US economy picks up just 266.000 April jobs as hiring slows sharply.

Economists had been forecasting stronger growth in US jobs as pandemic restrictions are gradually relaxed and Biden administration pumps trillions of dollars of fresh stimulus into the economy ${ }^{2}$.

The US economy is a highly developed mixed economy. It is the world's largest economy by nominal GDP (which estimated by $\$ 22.6$ trillion) and net wealth in 2021 . The United States has the most technologically powerful economy in the world and its firms are at the forefront in technological advances, especially in artificial intelligence, computers, pharmaceuticals and medical, aerospace, and military equipment. The expected GDP growth rate $7.5 \%$ in $2021^{3}$. So America is the leader and pioneer in all fields forever.

\section{I- Literature Review}

There are many articles and papers, such as sustainable development goals report: Egypt 2030, which showed the comparison between the United Nation's sustainable development goals (SDG), and Egypt's sustainable development strategy (SDS), referred to as Egypt's Vision $2030^{4}$.

In UK there are many studies, such as sustainable growth in the UK: Seizing opportunities from technological change and the transition to law-carbon economy, which published by London school of economics growth commission in December 2018. That is asserted on promoting strong, sustainable, balanced and inclusive growth is a priority for G20 governments, including the United Kingdom's, reflecting the need to drive improvements in labor and resource productivity through more and better investments in innovation ${ }^{5}$.

The United States obtains its best results on SDG 4 (Quality Education) and SDG 8 (Decent work and economic growth). Poverty, income inequalities, and universal access to health care and other public services remain important challenges. On sustainable development report on June 28, 2019, the report finds that no country in the world has achieved the 17 SDGs, based on trend data available, no country is on track for achieving the SDGs by $2030^{6}$.

\section{II- Dimensions of Sustainability}

The UN's 17 global goals aim to end poverty, protect the planet and ensure prosperity for every one by 2030 . The 17 live changing goals, outlined by the UN in 2015, these global goals, also known as the Sustainable Development Goals (GDSs). The aim is for all countries to work together to ensure no one is left behind. These goals are:

1- No Poverty. To end poverty, everyone should have basic health care, security and education.

2- Zero Hunger: Globally, one in mine people are undernourished this goal aims to end hunger.

3- Good Health: Ensuring people live healthy lives can cut child mortality and raise life expectancy.

4- Education: The UN wants everyone to have access to inclusive, equitable quality education.

5- Gender Equality: Gender equality is a human right, and is vital for a peaceful, prosperous world.

6- Clean water: Clean water prospects people from disease, yet three in 10 people lack access to it.

7- Clean Energy: Targets for 2030 include using more renewable affordable energy.

8- Economic Growth: the aim is for sustainable economic growth and decent employment for all.

9- Industry and Infrastructure: this involves building resilient infrastructure and fostering innovation.

10- No Inequality: The poorest $40 \%$ of the population should be able to grow their income faster than average.

11- Sustainability: The UN wants to increase affordable housing and make settlements inclusive, safe and sustainable.

12- Responsible Consumption: This goal aims to foster eco-friendly production, reduce waste and boost recycling.

13- Climate Action: Urgent action is needed, by regulating emissions and promoting renewable energy.

14- Life Under Water: The aim is to conserve and sustainably use the Oceans, Seas and marine resources.

15- Life on Land: To stop degradation, we must preserve forest, desert and mountain ecosystems.

16- Peace \& Justice: The aim is inclusive societies with strong institutions that provide justice for all.

\footnotetext{
${ }^{1}$ The Guardian (2021), “UK Economic Growth Next Year Will be Fastest Since 1948, Says OBR”, theguardian.com, accessed on May 04,2021.

2 The Guardian (2021), “US Economy Picks up ...”, May07, 2021, 16.31 BST, theguardian.com, accessed on May09,2021.

${ }^{3}$ Wikipedia (2021), "Economy of the United States", en.m.wikipedia.org, accessed on May09, 2021.

${ }^{4}$ UNDP (2018), "Sustainable Development Goals Report: Egypt 2030", UNDP and Fredrick S. Pardee Center for International Futures, University of Penver: USA and Egypt, P. 3.

${ }^{5}$ LSE (2018), "Sustainable Growth in the UK: Seizing Opportunities from Technological Change and the Transition to a Low-Carbon Economy", Centre for Economic Performance, Centre for Climate Change Economics and Policy, and Grantham Research Institute on Climate Change and the Environment: UK, P. 5

${ }^{6}$ UN (2019), "Sustainable Development Report", Sustainable Development Solutions Network: A Global Initiative for the United Nations, Sdgindex.org, accessed on May09, 2021.
} 
17- Partnership: If all countries are to achieve the goals, international cooperation is vital ${ }^{1}$.

Our paper concentrate on the global goal 8, which is concerned with sustainable economic growth in Egypt, UK, and USA. Because this goal is the main goal which is vital and very important goal (or the core) for all 17 SDGs, and USA, with UK are discovered the vaccines for COVID-19, also these two countries with Egypt are relaxed restrictions gradually and picked up growth rate with recovering.

We will use the Cobb-Douglas production function with the Solow growth model in long run, to determine the main sources of economic growth as following.

III- Rewriting the Cobb-Douglas production function and Solow Growth Model.

Cobb-Douglas Production Function (C-DPF) assumed that the quantity of capital and labor available in the economy is fixed, so the $(\boldsymbol{C}-\boldsymbol{D P F})$ is:
$\boldsymbol{Y}=\boldsymbol{F}(\boldsymbol{K}, \boldsymbol{L})$
$\left(K={ }_{K}^{-} \quad\right.$ and $\left.L={ }_{L}^{-}\right)$

Where Mishkin (2015) takes the (C-DPF) with applying on US economy with two observations:

First, an efficient, developed economy will generally produce more with the same quantity of capital and labor than inefficient, primitive economy.

Second, the shares of labor and capital income in US economy have remained relatively constant over time at about $70 \%$ labor, and $30 \%$ capital $^{2}$. So $(\boldsymbol{C}$-DPF $)$ will be.

$$
Y=F(K, L)=A K^{0.3} L^{0.7}
$$

The Solow model starts with the $(\boldsymbol{C}-\boldsymbol{D P P})$ with constant returns to scale as follow:

Where:

$$
Y_{t}=F\left(K_{t}, L_{t}\right)=A K_{t}^{0.3} L_{t}^{0.7}
$$

$Y_{t}=$ Output at time $t$

$K_{t}=$ Capital stock at time $t$

$L_{t}=$ Labor at time $t$

$\mathrm{A}=$ Available technology (measured by total factor productivity)

The $(\mathrm{t})$ time subscript notation is important, because what happens over time is central to discussing economic growth.

The Solo model looks at the economy in per-worker terms. If output at time $t$ is $Y_{t}$, then output per worker is $\frac{Y_{t}}{L_{t}}$, which we will represent with the lower case $\left(y_{t}\right)$. In the same way, consumption expenditure per worker is $c_{t}=\frac{c_{t}}{L_{t}}$, and investment per worker is $i_{t}=\frac{I_{t}}{L_{t}}$.

The amount of capital per worker, $k_{t}=\frac{K_{t}}{L_{t}}$, which we will refer to as the Capital-Labor ratio, play a very prominent role in the Solow model. To convert equation (3) into a per worker production function, we divide both sides by $L_{t}$ as follow:

$$
y_{t}=\frac{Y_{t}}{L_{t}}=\frac{A K_{t}^{0.3} L_{t}^{0.7}}{L_{t}}=\frac{A K_{t}^{0.3}}{L_{t}^{0.3}}=A k_{t}^{0.3}
$$

The Solow model assumes that (A) is exogenous, or given, so it does not say anything about how technology changes over time.

\section{Investment Function:}

With assuming that the economy is closed and that government spending is zero. So, in per-worker terms, this means that the total demand for output is:

$$
y_{t}=c_{t}+i_{t}
$$

In developing his model, Solow assumed that consumers save a fixed fraction ( $s$ ), the saving rate, of their income each year, so that saving per worker, $y-c$, is:

$$
y_{t}-c_{t}=s y_{t}
$$

Since, from equation (5), $i_{t}=y_{t}-c_{t}$. We can substitute to get.

$$
i_{t}=s y_{t}
$$

Substituting the per-worker production function, $y_{t}=A k_{t}^{0.3}$, into equation (7) we get the investment function:

Capital Accumulation:

$$
i_{t}=s A k_{t}^{0.3}
$$

Two forces determine changes in the capital stock: investment and depreciation. The Solow model assumes that a constant fraction $(\delta)$ of capital called the depreciation rate wears out each year.

Capital accumulation - the change in capital stock per-worker, $\Delta k_{t}=k_{t+1}-k_{t}$ equals new capital

\footnotetext{
${ }^{1}$ Sightsavers.org (2021), “Global Goals”, accessed on May09,2021.

${ }^{2}$ The more general form of $(\boldsymbol{C}-\boldsymbol{D P P})$ is written as $\boldsymbol{Y}=\boldsymbol{F}(\boldsymbol{K}, \boldsymbol{L})=\boldsymbol{A} K^{\alpha} L^{1-\alpha}$, as the $\alpha$ exponent on $\mathrm{K}$ is equal to the capital share of national income, while the (1- $\alpha)$ exponent on $L$ is the labor share of national income. The choice of the value of $\alpha=0.3$ is based on researchers estimates from historical data. For more details, see:

Mishkin, F. S (2015), “Macroeconomics: Policy and Practice”, (2 ${ }^{\text {nd }}$, Ed.), Pearson Global Edition: New York, PP 94-100.
} 
investment, it, minus the loss in terms of wear and tear of old capital or depreciation, $\delta k_{t}$ :

Where:

$$
\Delta k_{t}=i_{t}-\delta k_{t}
$$

$\Delta k_{t}=$ change in capital stock per worker

$i_{t}=$ investment per worker

$\delta k_{t}=$ Depreciation per warker

Equation (9) is the capital-accumulation equation. Substituting in for investment from the investment function, we can rewrite this equation as follows:

The Steady State:

$$
\Delta k_{t}=s A k_{t}^{0.3}-\delta k_{t}
$$

The steady state, the point at which capital per worker $k_{t}$ comes to rest and stops changing, occurs when $\Delta k_{t}=0$ :

$$
0=s A k_{t}^{0.3}-\delta k_{t}
$$

By adding $\delta k_{t}$ to both sides of the preceding equation, we derive the condition that describes when the steady state occurs ${ }^{1}$.

Investment $=$ depreciation

$$
s A k_{t}^{0.3}=\delta k_{t}
$$

Dynamics of the Solow growth model occurs.

1- If an economy invests more than it loses through depreciation, its capital stock will grow, and $y_{t}$ (output per worker) will grow also.

2- If technological changes occur (A), measured by productivity of labor increase, then investment will increase and capital accumulation will increase, so output per worker will grow and economic growth occurs.

That were happened in advanced countries like USA and UK, and that what Egypt should to do now, where the current country's administration according to advisers of economists and also Egyptian policy makers try to increase investments in all fields especially in infrastructure, building and construction sector, and technological changes in ICT sectors. To increase capital accumulation, which will lead to achieve high economic growth in long run in all three countries.

\section{IV- Sources of Sustainable Growth:}

According to (C-DPF) and its developing with Solow growth model, the main sources of sustainable growth in USA, UK, and Egypt are as follow:

1- Investment, which leads to increase capital accumulation, capital accumulation is the main factor to achieve economic growth.

2- Technological change through innovation and developing information and communication technology (ICT), (A), which measured by labor productivity. "productivity is not everything, but in the long run it is almost everything" (Paul Krugman). Over the long term, growth will be determined primarily by factors which determine productivity, and secondly those which improve labor participation.

3- The business environment: there are a range of factors in the business environment ( such as infrastructure, the efficiency of markets, market incentives, taxation and regulation) which effect on the productivity of firms and efficiency of the economy as a whole ${ }^{2}$.

4- Growth in the potential labor force: economists use the term "potential output" or "potential GDP" to describe the economy's maximum sustainable level of economic activity. Growth in potential GDP is determined by growth in potential labor (the number of people who want to be working when the labor market is strong), and growth in potential labor productivity.

The potential labor force, in turn, grows through native population growth and immigration, while potential labor productivity grows through business investment in tangible capital (machine, factories, offices, and stores) as well as investment in R\&D, and other intangible capital.

Improvements in labor quality due to education and training can also boost productivity, as can improvements in managerial efficiency or technology that allow business to produce more with the same amount of labor and capital ${ }^{3}$.

We can have reclassified these sources of sustainable growth for economic progress and development in advanced countries (USA and UK) as well as in developing countries such as Egypt, as follow:

5- Natural Factor: the quality and/or quantity of land or raw material.

6- Human and Physical Capital, and Technological Factors: the quality and/or quantity of human resources/ physical capital resources

\footnotetext{
${ }^{1}$ Ibid, PP 194-195.

${ }^{2}$ BIS (2021), "Sources of Economic Growth", Trade and Investment Analytical Papers topic 6 of 18, : UK, Department for Business Innovation \& Skills, DFID. Assets. Publishing. Service. Gov.uk, accessed on May17, 2021, PP 4-5.

${ }^{3}$ Ston, Chad (2017), “Economic Growth: Causes, Benefits, and Current Limits”, Center on Budget and Policy Priorities, April27, 2017: USA, cbpp.org/research/economic-growth-causes-benefits-and-current-limits, accessed on May17, 2021.
} 
7- Institutional Factors such as:

a- Finance and Banking System

b- Education System

c- Healthcare

d- Infrastructure

e- Political Stability ${ }^{1}$.

\section{V- Remarkable Conclusions:}

The US economy grew by an annualized $6.4 \%$ in first quarter of 2021 , following a $4.3 \%$ expansion in the previous three- month period and slightly beating market expectations of $6.1 \%$, the advance estimate showed. Activity and demand consolidated their recovery from last year's steep contraction, helped by reopening efforts amid an acceleration in the pace of COVID-19 vaccinations and continued government response related to the pandemic.

Increase in personal consumption expenditures (PCE), non-residential fixed investment, federal government spending, residential fixed investment, and state and local government spending were partly offset by decreases in private inventory and exports ${ }^{2}$.

US economy will be grow rabidly after completing COVID-19 vaccination for all American residencies, the growth rate of GDP may be jump for more than $10 \%$, because the American economists have been learnt from the previous experiences, and all economic activities will expansion in the next half of 2021, and they will continue progressing forever in the next years.

UK's GDP is estimated to have increased by a record $16.0 \%$ in quarter 3 (July to Sep) 2020, revised from the first estimate of $15.5 \%$ growth $^{3}$.

UK with USA set for the two strongest economic growth in the world, since WWII, forecasts bank of England, because interest rates in UK and also in USA to be kept at record low of $0.1 \%$ with UK's GDP growth and USA's GDP growth now forecast to rise at $7.25 \%$ and from $6.4 \%$ to more than $10 \%$ in 2021 in the two countries respectively ${ }^{4}$

The UK GDP growth rate will be increase gradually in 2022 after all English people have vaccine. The UK will maintain its lead at the top of growth with the United States in all economies of the world in the next years forever.

Egypt is one of the emerging economies, which was able to achieve a growth rate of 5.9\% in 2019, and despite coronavirus epidemic on the economy, it is still one of the highest growth rate in the developing countries in the world.

Egypt's economy has been expected to recover from this pandemic and achieve a growth rate more than $6 \%$ at the end of 2021 by us, and it will be gradually improving. Because the current Egyptian administration has been making big bush by massive investments in all economic fields especially in infrastructure, roads, bridges, construction and building sectors, which will be yielded positive externalities in all sectors of the economy.

\section{VI- Same Advices for Policy Makers:}

1- Concentrating on capital accumulation and technological advanced in all sectors.

2- Sustainable growth requires giving more attention to environment, especially climate change, and its causes such as reducing rise greenhouse gases and assuring on green economy.

3- High level of education and continues training for worker are vital elements for building human capital, which is necessary for sustainable growth.

4- Infrastructure and advanced telecommunications are the main bases for economic development and sustainable growth.

5- Health care is more important now than any time before, because COVID-19 is effecting on all economic activities.

6- Modern Mixed Economy (MME) system is the best economic system, which is applying in USA, UK, and Egypt. That should be followed in any economy to achieve sustainable growth, with keeping on social responsibility of firms and private sector. Governments should be give more attention for transfer payments such as, unemployment insurance benefits, social security benefits, Medicare or welfare payments.

\footnotetext{
${ }^{1}$ Kokminglee.125mb.com/economics/sourcesdev.htm, accessed on May17, 2021

${ }^{2}$ US Bureau of Economic Analysis (2021), “United States GDP Growth Rate", Trading Economics: USA, tradingeconomics.com/unitedstates/gdp-growth, accessed on May21, 2021.

3 Office for National Statistics (2021), “GDP Quarterly National Accounts, UK: July to September 2020", ons.gov.uk/economy/grossdomesticproductgdp, accessed on May21,2021.

${ }^{4}$ Compare: -

US Bureau of Economic Analysis (2021), Op Cit.

Bank of England (2021), "UK Set for Strongest Economic Growth Since WWII ... ", The

Gaurdian.com/business/2021/may/06/uk-braces-for-strongest-economic-growth-since-wwii-forecasts-bank-of-england, accessed on May21, 2021.
} 
7- Strong institutions are essentially factor for sustainable development. Because that provide justice for all.

Finally, USA and UK are large developed modern mixed economies, but Egypt is small developing modern mixed economy. So all policies that has been applying on large economies can be useful and possible to apply on small emerging countries, because both categories followed modern mixed economy system.

\section{References}

Afdb.org, accessed on May 12, 2021.

Bank of England (2021), "UK Set for Strongest Economic Growth Since WWII ... “, The Gaurdian.com/business/2021/may/06/uk-braces-for-strongest-economic-growth-since-wwii-forecasts-bankof-england, accessed on May21, 2021.

BIS (2021), "Sources of Economic Growth", Trade and Investment Analytical Papers topic 6 of 18, : UK, Department for Business Innovation \& Skills, DFID. Assets. Publishing. Service. Gov.uk, accessed on May17, 2021.

Ikram, Khalid (2006), “The Egyptian Economy 1952-2000: Performance, Policies, and Issues”, Routledge Studies in Middle Eastern Economies, Routledge: Great Britain and USA.

Kokminglee.125mb.com/economics/sourcesdev.htm, accessed on May17, 2021.

LSE (2018), "Sustainable Growth in the UK: Seizing Opportunities from Technological Change and the Transition to a Low-Carbon Economy", Centre for Economic Performance, Centre for Climate Change Economics and Policy, and Grantham Research Institute on Climate Change and the Environment: UK.

Mishkin, F. S (2015), "Macroeconomics: Policy and Practice”, (2 $2^{\text {nd }}$, Ed.), Pearson Global Edition: New York.

Office for National Statistics (2021), “GDP Quarterly National Accounts, UK: July to September 2020”, ons.gov.uk/economy/grossdomesticproductgdp, accessed on May21,2021.

Sightsavers.org (2021), “Global Goals", accessed on May09,2021.

Ston, Chad (2017), “Economic Growth: Causes, Benefits, and Current Limits”, Center on Budget and Policy Priorities, April27, 2017: USA, cbpp.org/research/economic-growth-causes-benefits-and-current-limits, accessed on May17, 2021.

The Guardian (2021), "UK Economic Growth Next Year Will be Fastest Since 1948, Says OBR", theguardian.com, accessed on May 04,2021.

The Guardian (2021), “US Economy Picks up ...”, May07, 2021, 16.31 BST, theguardian.com, accessed on May09,2021.

UN (2019), “Sustainable Development Report”, Sustainable Development Solutions Network: A Global Initiative for the United Nations, Sdgindex.org, accessed on May09, 2021.

UNDP (2018), "Sustainable Development Goals Report: Egypt 2030", UNDP and Fredrick S. Pardee Center for International Futures, University of Penver: USA and Egypt, P. 3.

US Bureau of Economic Analysis (2021), "United States GDP Growth Rate", Trading Economics: USA, tradingeconomics.com/united-states/gdp-growth, accessed on May21, 2021.

WIKIPEDIA (2021), "Economy of the UK", en.m.wikipedia.org, accessed on May 04, 2021.

Wikipedia (2021), “Economy of the United States”, en.m.wikipedia.org, accessed on May09, 2021. 